Arq. Bras. Med. Vet. Zootec., v.69, n.4, p.830-834, 2017

\title{
Papillary Adenocarcinoma of the descending colon in a dog: case report
}

[Adenocarcinoma papilífero em cólon descendente de cão: relato de caso]

M.G.P.A. Ferreira, J.O. Ribeiro, A.L. Pascoli, N.P. Reis-Filho, T. Beluque, M.Q.P. Santos, S.S. Theodoro, M.A.R. Feliciano ${ }^{*}$, A.B. Nardi, M. Tinucci-Costa, P.C. Moraes, J.C. Canola, A.C. Carciofi

Universidade Estadual Paulista "Júlio de Mesquita Filho"- UNESP - Jaboticabal, SP

\begin{abstract}
The aim of this report was to describe the clinical findings and therapeutic management of a case of papillary adenocarcinoma of the descending colon in a Beagle. The patient presented soft stools, haematochezia, tenesmus, and dyschezia. Clinical examination revealed alterations on the ultrasonographic features of the descending colon suggestive of colitis and neoplasia. Following local mass resection, histopathology analysis revealed mild lymphoplasmocytic enteritis and papillary adenocarcinoma of the colon. Enterectomy for tumoral resection and biopsy of locoregional lymph nodes were carried out. Subsequent to the surgical procedure, it was possible to confirm the previous diagnosis and the tumor was classified as intestinal intraluminal papillary adenocarcinoma, with incomplete surgical margins. Adjuvant chemotherapy was performed using carboplatin, cyclophosphamide, and piroxicam, leading to remission of clinical signs and absence of any clinical or imaging alterations compatible with the patient's previous clinical condition.
\end{abstract}

Keywords: canine, intestinal neoplasia, oncology

\section{RESUMO}

O objetivo desse relato de caso foi descrever os achados clínicos e manejo terapêutico de um caso de adenocarcinoma papilífero do cólon descendente em um Beagle. O paciente apresentou fezes amolecidas, hematoquesia, tenesmo e disquesia. Exame clínico revelou alteração de achados ultrassonográficos do cólon descendente sugerindo colite e neoplasia. Após ressecção de massa local, análise histopatológica revelou enterite linfmoplasmocito leve e adenocarcinoma papilar do cólon. Enterectomia para ressecção tumoral e biopsia das lesões locais e tumores linfonodais foram realizadas. Após procedimento cirúrgico foi possível confirmar o diagnóstico prévio e o tumor foi classificado como adenocarcinoma papilar intraluminal intestinal, com margens cirúrgicas incompletas. Quimioterapia adjuvante foi realizada utilizando carboplatina, ciclofosfamida e piroxano, levando a remissão de sinais clínicos e ausência de alterações de imagem compatíveis com situação clínica prévia do paciente.

Palavras-chave: canino, neoplasia intestinal, oncologia

\section{INTRODUCTION}

The canine gastrointestinal tract is a potential site for several primary tumors, which can arise from the intestinal stroma, round cells, neuroendocrine system, and/or epithelial cells from the intestinal crypts; and can affect any segment of the small or large intestine (Head et al., 2002; Gomes et al., 2014).

Recebido em 26 de setembro de 2016

Aceito em 11 de outubro de 2016

*Autor para correspondência (corresponding author)

E-mail: marcusfeliciano@yahoo.com.br
Intestinal neoplasias are uncommon in dogs, representing only $1 \%$ of tumors in this species (Sobral et al., 2008). Lymphomas are the most common intestinal tumors, followed by adenocarcinomas, which correspond to 0.18 to $0.3 \%$ of cases (Head et al., 2002). The incidence of bowel tumors is higher in older patients, affecting predominantly male animals aged between six and nine years old (Selting, 2013). Collies and German Shepherds seem to be more likely predisposed to intestinal adenocarcinomas than other breeds (Selting, 2013). 
The aim of the present report is to describe the clinical and ultrasonographic abnormalities and the therapeutic management of a canine patient diagnosed with papillary adenocarcinoma of the large intestine, in light of the fact that this is a rare tumor of the descending colon in dogs.

\section{CASE REPORT}

An 8-year-old Beagle was admitted to the "Governador Laudo Natel" Veterinary Hospital of the UNESP - Univ Estadual Paulista, Jaboticabal-SP, Brazil, with a history of soft stools since it was a puppy, haematochezia for four years, and tenesmus and dyschezia for six months. The patient had already undergone several treatments using antibiotics, gastric protectors, steroids, and therapeutic diets but with no any significant clinical improvement.
Physical examination, abdominal palpation, blood cell count, biochemical profile (creatinine, blood urea nitrogen, alanine aminotransferase, alkaline phosphatase, total protein, and albumin analysis), fecal examination, abdominal ultrasonography, and conventional and contrastenhanced radiography of the gastrointestinal tract were performed. No significant alterations were observed, with the exception of abdominal ultrasonography; in which thickening of the intestinal wall was noted (end portion of the descending colon $-8.1 \mathrm{~mm}$ ) with preserved intestinal layers but increased echogenicity of the mucosa (Figure 1-A), suggestive of colitis. Moreover, on the same region, there was a portion of the colon with loss of normal stratification of the intestinal layers and hyperechoic and heterogeneous echotexture (Figure 1-B), suggestive of neoplasia.
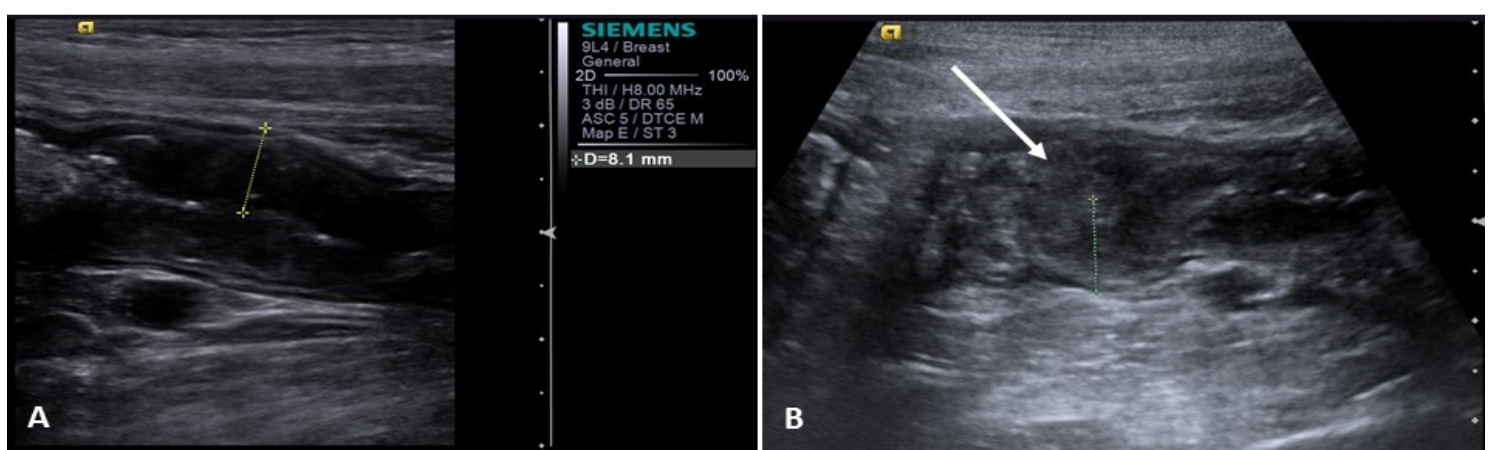

Figure 1. Ultrasonographic image of the descending colon in a Beagle later diagnosed with intestinal intraluminal papillary adenocarcinoma. (A): intestinal wall thickening $(8.1 \mathrm{~mm})$, preserved stratification, and increased echogenicity of the mucosa; (B): loss of intestinal stratification, and hyperechoic and heterogeneous echotexture (arrow), suggestive of neoplasia.

An incisional biopsy was carried out through exploratory laparotomy, during which samples of jejunal and descending colon loops were obtained and the thickening of the wall of the end portion of the colon was observed $(3 \mathrm{~cm}$ long). Histopathology analysis of the biopsied material revealed mild intestinal lymphoplasmocytic enteritis and papillary adenocarcinoma of the colon.

Enterectomy and enteroanastomosis were recommended to resect the tumor and excise at least two mesenteric lymph nodes for accurate clinical staging. During the surgical procedure, an intestinal fragment of approximately $4 \mathrm{~cm}$ with a black and papillomatous surface was obtained (Figure 2). Further 2 fragments, of $0.8 \mathrm{~cm}$ in diameter, were collected from incisional biopsies of two mesenteric lymph nodes. The samples were submitted to histopathology analysis for histogenesis, and better determination of surgical margins and lymph node involvement. Microscopic analysis revealed a malignant exophytic neoplasm that projected into the intestinal lumen characterized by papillary arrangements of cells with moderate pleomorphism, large and hyperstained nuclei, and eosinophilic and vacuolated cytoplasm; interspersed with caliciform cells and compatible with intraluminal intestinal papillary adenocarcinoma. Analysis detected compromised surgical margins but the lymph nodes were free from metastatic lesions. 


\section{Ferreira et al.}

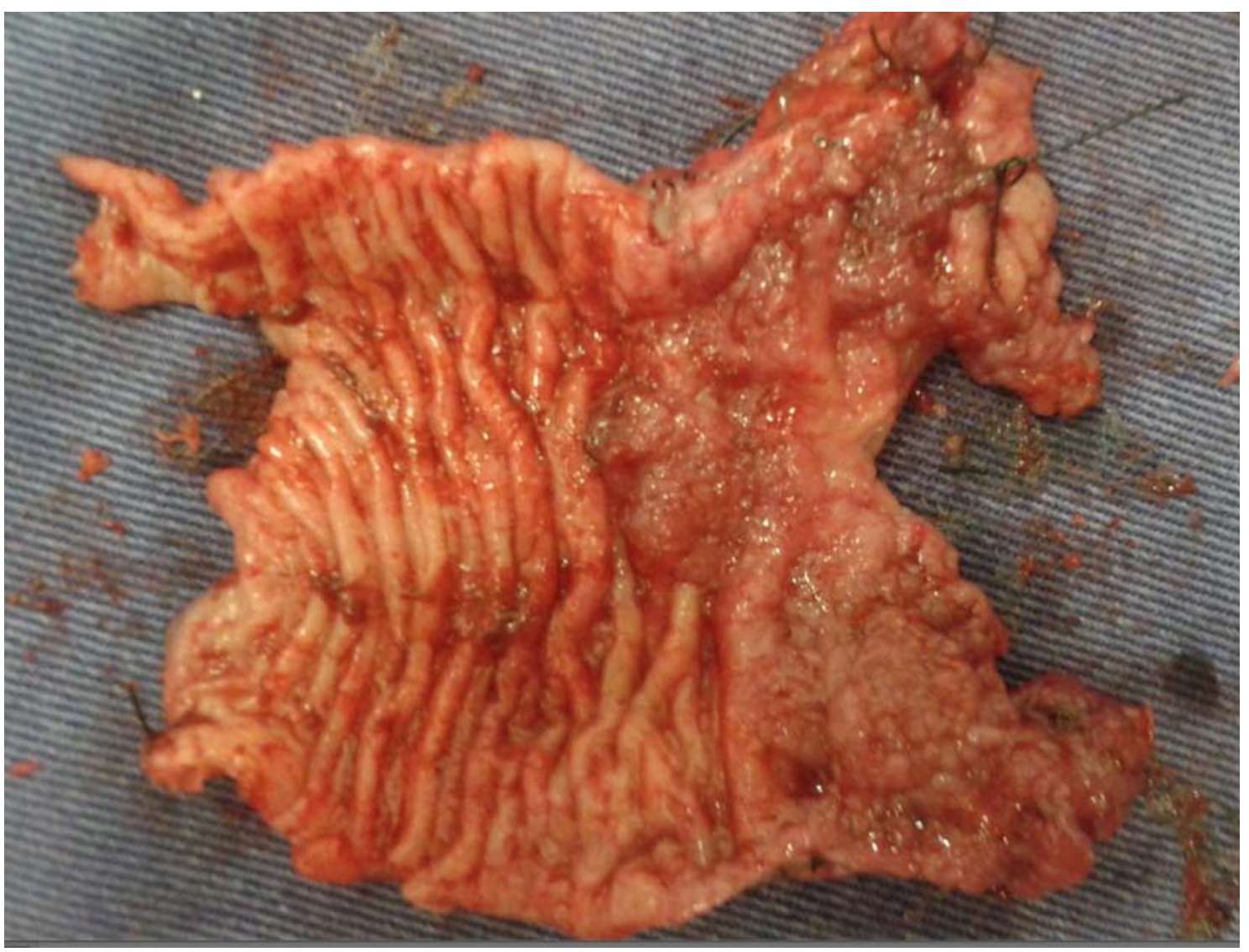

Figure 2. Photograph of the mucosal changes of the descending colon in a dog diagnosed with intestinal intraluminal papillary adenocarcinoma. Despite performing osteotomy of the pubic bone, the technique did not allow the complete resection.

In addition to the surgical procedure, adjuvant chemotherapy was recommended using $300 \mathrm{mg} / \mathrm{m}^{2}$ carboplatin intravenously (every 21 days, for six applications) and $12.5 \mathrm{mg} / \mathrm{m}^{2}$ cyclophosphamide orally (every 48 hours) alternated with $0.3 \mathrm{mg} / \mathrm{kg}$ piroxicam (every 48 hours, for six months).

At subsequent checkups and chemotherapy sessions, the patient was reassessed and found to be in good general condition; however, there was a lot of sensitivity during rectal palpation and defecation. Thus, $25 \mathrm{mg} / \mathrm{kg}$ dipyrone and 3 $\mathrm{mg} / \mathrm{Kg}$ tramadol hydrochloride (every 8 hours) were prescribed. As the owner reported no clinical improvement, $10 \mathrm{mg} / \mathrm{kg}$ gabapentin was given every 12 hours, for 30 days, but only discrete clinical improvement was noted. Therefore, 1 (one) capsule of ETNA ${ }^{\circledR}$ (Gross, Brasil) was prescribed every 24 hours, for 30 days. After seven days of medication, the owner reported significant improvement of pain symptoms and, thus, tramadol hydrochloride and dipyrone were discontinued and gradual reduction of gabapentin was carried out until completely suspended. After 30 days, the patient no longer showed pain during rectal palpation and, after 60 days, ETNA ${ }^{\circledR}$ was suspended.

Currently, the patient is in good general condition, with 24 months of clinical remission, and without any manifestation associated with neoplasia. The animal has been re-evaluated every 3 months by general and specific physical examination, and image analysis such as chest radiography and abdominal ultrasonography.

\section{DISCUSSION}

According to Head et al. (2002), more than $60 \%$ of all intestinal tumors in small animals are located in the colon and rectum, as observed in the present report. However, intestinal carcinomas are rare and, according to Yamamoto 
et al. (1993), when present are often histological subtypes of tubular adenocarcinoma; a fact that denotes significance to the uncommon occurrence of the papillary type in the descending colon, not yet described in the veterinary literature.

The symptomatology of the patient (symptoms and clinical course) was consistent with chronic inflammatory bowel disease (Hall and German, 2005). This chronicity may be considered a predisposing factor for neoplasia development, as the more intense and lasting (as observed in the present report) the oxidative stress is to the mucosal epithelium of the colon, the greater the risk of neoplasia developing (Seril et al, 2003).

The diagnosis of intestinal tumors in dogs is carried out by a combination of clinical history, symptomatology, physical examination, complementary test (including abdominal ultrasography), and histopathology analysis (Radlinsky, 2013). In this report, ultrasonography was important in identifying and characterizing (location, shape, and ultrasonographic features) the intestinal lesion and predetermining the malignancy of the lesion; thus aiding diagnosis and subsequent clinical and therapeutic management, as suggested by Garcia and Froes (2012). The ultrasonographic findings observed in this report were compatible with neoplastic abnormalities of the gastrointestinal tract (loss of the normal intestinal stratification) (Silva et al. 2015).

Intestinal carcinomas usually have poor prognosis, with mean survival time ranging from six to ten months. However, when metastases are present at the moment of the diagnosis, the average survival time is approximately three months (Crawshaw et al., 1998). It must be noted that the treatment protocol adopted in this study was able to keep the patient in clinical remission and provide longer survival time than the reports available in the literature. On the other hand, in colorectal adenocarcinomas cases in which rectal amputation enables complete tumor resection, an average survival time of two to four years can be attained (Swiderski and Withrow, 2009).

The curative treatment can be achieved through wide resection of the primary tumor when there is no evidence of distant metastases (Crawshaw et al., 1998; Swiderski and Withrow, 2009).
However, in the present case report, histopathology revealed that microscopic disease was still present after surgical resection; therefore, adjuvant therapy was recommended.

The benefits of adjuvant chemotherapy in the resection of intestinal epithelial tumors in dogs are still unclear. Moreover, the chemotherapy reports available are often inconsistent in the number of cases, standardization of protocols, and clinical staging of the patients evaluated (Sobral et al., 2008; Radlinsky, 2013; Selting, 2013). It is believed that the inclusion of carboplatin combined with piroxicam and cyclophosphamide in a metronomic regime contributed to the maintenance of clinical remission observed in the patient and consequent absence of any imaging findings indicative of the disease. The protocol adopted in this report was safe, well tolerated, and could be applied in the treatment of other intestinal tumors in dogs.

\section{CONCLUSION}

Although uncommon, intestinal adenocarcinomas are tumors that can have a poor prognosis for patients, especially when diagnosed late. In conclusion, ultrasonography is a useful tool in the diagnosis of papillary adenocarcinoma of the descending colon in dogs and surgical resection combined with adjuvant chemotherapy can provide superior disease-free survival time with good quality of life.

\section{REFERENCES}

CRAWSHAW, J.; BERG, J.; SARDINAS, J.C. et al. Prognosis for dogs with non lymphomatous, small intestinal tumors treated by surgical excision. J. Am. Anim. Hosp. Assoc., v.34, p.451-456, 1998

GARCIA, D.A.A.; FROES, T.R. Errors in abdominal ultrasonography in dogs and cats. $J$. Small Anim. Pract., v.53, p.514-519, 2012.

GOMES, R.G.; LACERDA, A.M.D.; SILVA, E.C. et al. Diagnóstico diferencial de neoplasia maligna de células redondas intestinal em cão (Canis lupus familiaris). In: SEMANA CIENTÍFICA PROFESSOR DR. BENJAMIN EURICO MALUCELLI, 23., 2014, São Paulo. Anais... São Paulo: FMVZ/USP, 2014. p.10. 
HALL, E.J.; GERMAN, A.J. Diseases of the small intestine. In: ETTINGER, S.J.; FELDMAN, E.C. Textbook of veterinary intestinal medicine: diseases of the dog and cat. Saint Louis: Elsevier, 2005. p.1332-1378.

HEAD, K.W.; ELSE, R.W.; DUBIELZIG, R.R. Tumors of the alimentary tract. In: MEUTEN, D.J. (Ed.). Tumors in domestic animals. 4.ed. AMES: [Wiley], 2002. p.426-430.

RADLINSKY, M.G. Surgery of the digestive system. In: FOSSUM, T.W. et al. Small animal surgery. 4.ed. Missouri: Elsevier, 2013. 422p.

SELTING, K.A. Intestinal Tumor. In WITHROW, S.J. et al. Small animal clinical oncology. 5.ed. Missouri: Elsevier, 2013. 412p.

SERIL, D.N.; LIAO, J.; YANG, G.Y.; YANG, C.S. Oxidative stress and ulcerative colitis-associated carcinogenesis: studies in humans and animals models. Carcinogenesis, v.24, p.353-362, 2003.
SILVA, M.A.F.; SANSON, B.C.; FROES, T.R. Intestinos. In: FELICIANO, M.A.R.; CANOLA, J.C.; VICENTE, W.R.R. (Eds.). Diagnóstico por imagem em cães e gatos. São Paulo: MedVet, 2015. p.514-547.

SOBRAL, R.A.; HONDA, S.T.; KATAYAMA, M.L.H. et al. Tumor slices as a model to evaluate doxorubicin in vitro treatment and expression of trios of genes PRSS11, MTSS1, CLPTM1 and PRSS11, MTSS1, SMYD2 in canine mammary gland cancer. Acta Vet. Scand., v.50, p.27, 2008.

SWIDERSKI, J.; WITHROW, S. A novel surgical stapling technique for rectal mass removal: a retrospective analysis. J. Am. Anim. Hosp. Assoc., v.45, p.67-71, 2009.

YAMAMOTO, S.; MOCHIZUKI, H.; HASE, K. et al. Assessment of clinic pathologic features of colorectal mucinous adenocarcinoma. Am. J. Surg. Pathol., v.166, p.257-261, 1993. 